\title{
Frontal cortex chitinase and pentraxin neuroinflammatory alterations during the progression of Alzheimer's disease
}

\author{
Marta Moreno-Rodriguez ${ }^{1}$, Sylvia E. Perez ${ }^{1}$, Muhammad Nadeem ${ }^{1}$, Michael Malek-Ahmadi ${ }^{2}$ and Elliott J. Mufson ${ }^{1 *}$ (D)
}

\begin{abstract}
Background: Chitinase 3-like 1 (CHI3L1), chitinase 3-like 2 (CHI3L2), and neuronal pentraxin II (NPTX2) are inflammatory biomarkers of Alzheimer's disease (AD). Although studies have demonstrated that cerebrospinal fluid levels of these proteins are changed in $A D$, no studies have undertaken a detailed examination of alterations in protein levels, cellular expression, and interaction with amyloid in the brain during the progression of AD.
\end{abstract}

Methods: The study evaluated levels of both CHI3L1 and CHI3L2, NPTX2, ionized calcium-binding adapter molecule 1 (Iba1), complement component 1q (C1q), glial fibrillary acidic protein (GFAP), and CD44, in the frontal cortex of people who died with an antemortem clinical diagnosis of no cognitive impairment (NCl), mild cognitive impairment $(\mathrm{MCl})$, mild/moderate $A D(m A D)$, and severe $A D(S A D)$ using immunoblot and immunohistochemical techniques.

Results: CHI3L1-immunoreactive (-ir) astrocyte numbers were increased in the frontal cortex and white matter in SAD compared to $\mathrm{NCl}$. On the other hand, increases in GFAP and Iba1-ir cell numbers were observed in $\mathrm{MCl}$ compared to $\mathrm{NCl}$ but only in white matter. Western blot analyses revealed significantly lower frontal cortex CHI3L2 levels, whereas CD44 levels were increased in SAD. No significant differences for CHI3L1, GFAP, C1q, and NPTX2 protein levels were detected between clinical groups. Strong significant correlations were found between frontal cortex CHI3L1 and Iba1-ir cell numbers in white matter and CHI3L1 and C1q protein levels in the early stages of the disease. C1q and Iba1, CD44 with CHI3L2, and GFAP protein levels were associated during disease progression. CHI3L1 and Iba1 cell numbers in white matter showed a significant associations with episodic memory and perceptual speed.

Conclusions: White matter CHI3L1 inflammatory response is associated with cognitive impairment early in the onset of AD.

Keywords: Alzheimer's disease, Astrocytes, Chitinase, Cognitive impairment, Frontal cortex, Gray matter, Microglia, Neuroinflammation, Pentraxin, White matter

\section{Introduction}

Alzheimer's disease (AD) is an irreversible, progressive neurodegenerative disorder resulting in cognitive decline leading to extreme societal costs $[1,2]$. With a rapidly growing older population worldwide, defining the cellular mechanism(s) driving the onset of $\mathrm{AD}$ is of paramount importance. AD-related cognitive decline is manifested by

\footnotetext{
* Correspondence: Elliott.mufson@dignityhealth.org

'Department of Neurobiology and Neurology, Barrow Neurological Institute, St. Joseph's Hospital and Medical Center, 350 W. Thomas Rd., Phoenix, AZ 85013, USA

Full list of author information is available at the end of the article
}

deficits in working memory and executive function modalities associated, in part, with the frontal cortex (FC) [3]. The FC is a hub of the default mode network that displays extensive amyloid pathology associated with cognitive decline early in $\mathrm{AD}[4,5]$. However, the underlying cellular mechanism(s) driving FC dysfunction remains unknown.

$\mathrm{AD}$ is pathologically characterized by the accumulation of amyloid-beta $(A \beta)$ plaques, tau neurofibrillary tangles (NFTs), synaptic and neuronal loss, glial activation, and neuroinflammation [6-11]. $A \beta$ plaques and NFTs induce an immune response associated with 
astroglia and microglia activation and increased inflammatory mediators, tumor necrosis factor $\alpha$ [12], S100, interleukin 1 [13, 14], such as triggering receptor expressed on myeloid cells 2 (TREM2) $[15,16]$, and complement activation ( $\mathrm{C} 1 \mathrm{q}$ to $\mathrm{C} 5 \mathrm{~b}-9)$ [17] in $\mathrm{AD}$ [18-20]. Recently, the chitinase family of inflammatory proteins, particularly chitinase 3 -like 1 (CHI3L1, YKL-40, or HC gp-39), chitinase 3-like 2 (CHI3L2 or YKL-39), and pentraxin II (NPTX2 or Narp), a member of the pentraxin family, has been associated with $\mathrm{AD}$ pathogenesis [21, 22]. Although their functions are not well understood, it is hypothesized that chitinases are involved in pro-inflammatory and proangiogenic tissue remodeling in cancer $[23,24]$ as well as in several neurodegenerative diseases [25-32]. CHI3L1 found in the cerebral spinal fluid (CSF) obtained from preclinical and prodromal cases of $\mathrm{AD}$ [33-35] has been suggested as a biomarker for discerning cognitively normal from mild cognitive impairment (MCI) individuals [25, 36, 37]. Human tissue-based studies revealed that CHI3L1 is expressed in astrocytes in close apposition to blood vessels, $A \beta$ plaques and NFTs in AD [38]. However, the role that chitinases play in cognitive impairment during the progression of $\mathrm{AD}$ remains under-investigated.

The protein NPTX2, a member of the pentraxin family $[39,40]$, is involved in excitatory synapse formation $[41,42]$ and has been implicated in the regulation of neuroinflammatory responses associated with trauma and neurological disease. For example, the deletion of NPTX2 produces an alteration of microglial activation following sciatic nerve transection [43]. Interestingly, reduced CSF levels of NPTX2 were associated with medial temporal lobe atrophy and cognitive decline in $\mathrm{AD}$ [44].

Although CSF chitinase and NPTX2 neuroinflammatory proteins are putative biomarkers related to the pathogenesis and cognitive decline seen in $\operatorname{AD}[45,46]$, there are virtually no detailed clinicopathological studies of these proteins in brain tissue during the clinical onset of AD. Therefore, we examined CHI3L1 and NPTX2 protein levels and cellular expression in the FC, a region affected early by plaque pathology during the progression of $\mathrm{AD}$. These proteins were compared with other glial neuroinflammatory markers such as microglial ionized calcium-binding adapter molecule 1 (Iba1), complement component 1q (C1q), TREM2, astrocytic glial fibrillary acidic protein (GFAP), and glial surface adhesion glycoprotein $\mathrm{CD} 44$, which interacts directly with CHI3L1 [47] and drives immune responses in the central nervous system [48]. These proteins were quantified using immunoblotting and immunohistochemistry or immunofluorescence techniques. Changes in these markers were correlated with case demographics and cognitive and neuropathological variables.

\section{Methods \\ Subjects}

The individuals used in this study were selected based upon a premortem clinical diagnosis of no cognitive impairment (NCI, $n=15$ ), mild cognitive impairment (MCI, $n=15)$, and mild to moderate AD (mAD, $n=14$ ) from the Rush Religious Orders Study (RROS) cohort (Table 1) and severe $\mathrm{AD}(\mathrm{sAD}, n=12)$ from the Rush Alzheimer's Disease Center. Subject selection was not based upon NFT Braak, amyloid Thal, or ApoE criteria. Association of these variables with the present findings was evaluated after the study was completed to avoid pathological bias. The Human Research Committees of Rush University Medical Center approved this study, and informed consent for research and autopsy was obtained from RROS participants or family/ guardians.

\section{Clinical and neuropathological characteristics}

Table 1 shows the demographic, clinical and neuropathological characteristics of the RROS cases examined. Clinical and neuropathological criteria for $\mathrm{NCI}, \mathrm{MCI}$, and AD diagnosis were reported previously [49-53]. Briefly, after a review of the clinical data and examination of the participant, clinical diagnoses were made by a board-certified neurologist with expertise in gerontology. The neurologist reviewed medical history, medication use, neurologic examination information, results of cognitive performance testing, and the neuropsychologist's opinion of cognitive impairment and the presence of dementia. Each participant was evaluated in his/her home, emphasizing clinically relevant findings. AD diagnosis of dementia followed the recommendations of the joint working group of the National Institute of Neurological and Communicative Disorders and the Stroke and the Alzheimer's Disease and Related Disorders Association (NINCDS/ADRDA) [54]. Although there are no consensus criteria for the clinical classification of mild cognitive impairment, the criteria used in the present study are compatible with those used by many others in the field to describe those persons who are not cognitively normal, but do not meet the accepted criteria for dementia [55-60]. Here, MCI was defined as persons rated as impaired on neuropsychological testing by the neuropsychologist but were not found to have dementia by the examining neurologist. Average time from the last clinical evaluation to death was $\sim 8$ months.

Clinical neuropsychological testing included Mini-Mental State Examination, global cognitive score, composite $\mathrm{z}$ score compiled from 19 cognitive tests [61], and z-scores from episodic memory, semantic memory, working memory, perceptual speed, and visuospatial tests. Postmortem neuropathology was performed as reported previously [15, 49-51, 53], which included Braak 


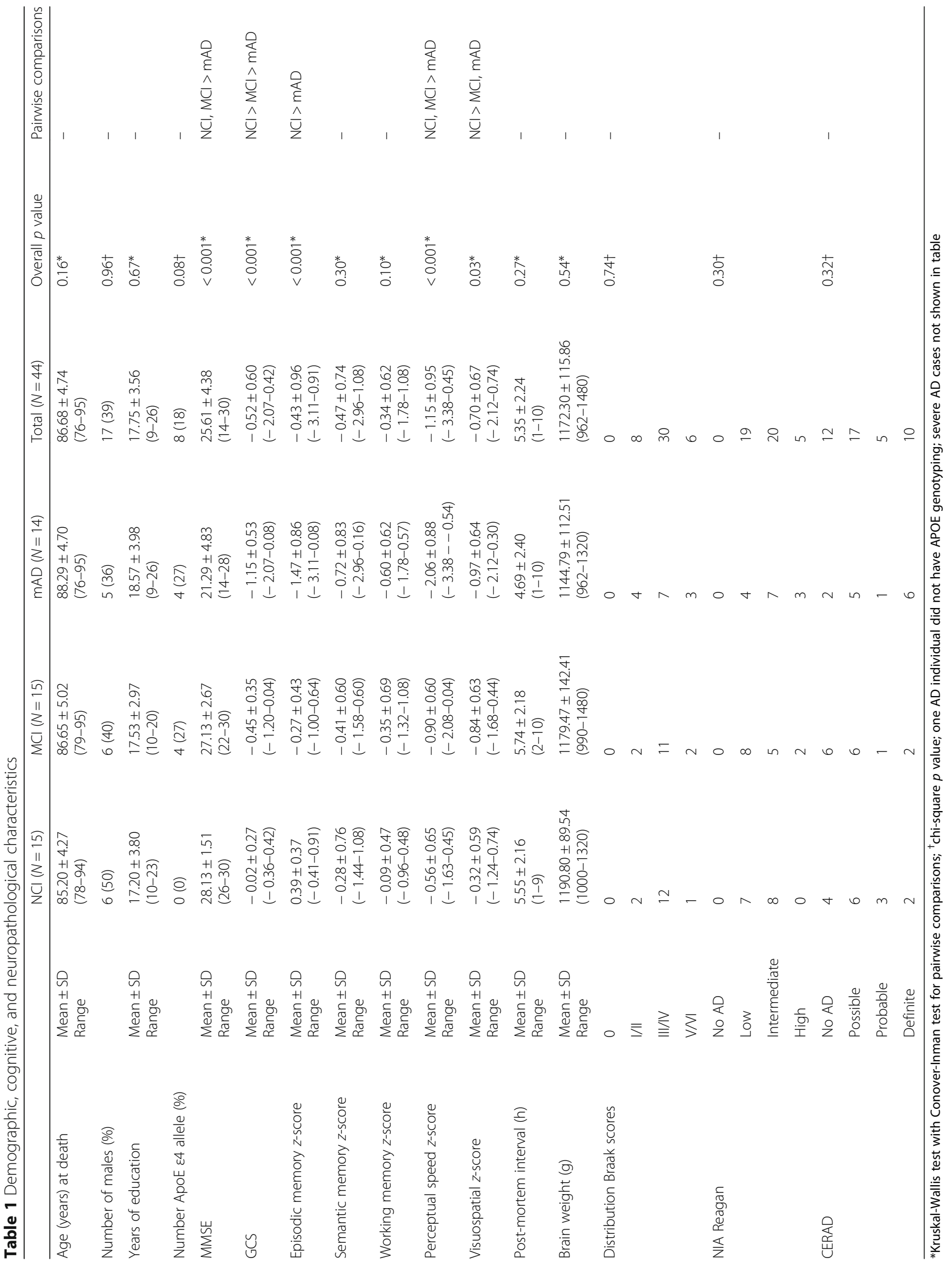


staging [62], NIA-Reagan criteria [63], and the Consortium to Establish a Registry for Alzheimer's Disease (CERAD) [64]. A board-certified neuropathologist excluded cases with other pathologies (e.g., cerebral amyloid angiopathy, vascular dementia, dementia with Lewy bodies, hippocampal sclerosis, Parkinson's disease, and large strokes) and those treated with acetylcholinesterase inhibitors. The RROS neuropathology core includes the transactive response DNA-binding protein of $43 \mathrm{kDa}$ (TDP-43) [65] in their diagnosis. A similar detailed clinical and neuropathological evaluation were not available for the SAD cases.

\section{Quantification of pathological lesions}

Neuritic plaques, diffuse plaques, and NFT counts were performed within a $1-\mathrm{mm}^{2}$ area $(\times 100$ magnification $)$ per neocortical region blinded to clinical data [66-68] using Bielschowsky silver stain and AT8 immunohistochemistry. Amyloid precursor protein (APP)/A $\beta$ was used to analyze the $A \beta$ load [69]. Standardized plaque and tangle counts from each area were converted to standard scores by dividing the standard deviation of mean raw counts per marker and region from the entire deceased cohort. Quantitation of amyloid load was performed by using images from $A \beta$ labeled sections [69] to determine percent area occupied using Object-Image 1.62p15 [70].

\section{Antibodies}

Characteristics of primary and secondary antibodies used for immunohistochemical, immunofluorescence, and western blotting experiments are described in Table 2.

\section{Western blotting}

FC (Brodmann's area 10) CHI3L1, CHI3L2, NPTX2, GFAP, C1q, Iba1, and CD44 protein levels were measured in $15 \mathrm{NCI}, 15 \mathrm{MCI}, 13 \mathrm{mAD}$, and $7 \mathrm{sAD}$ samples [15]. Briefly, frozen samples were homogenized $(150 \mathrm{mg} / \mathrm{mL})$ in phosphate buffer containing protease inhibitors (Sigma, St. Louis, MO) and denatured in SDS loading buffer to a final concentration of $5 \mathrm{mg} / \mathrm{ml}$. Proteins $(50 \mu \mathrm{g} / \mathrm{sample})$ were separated by SDS-PAGE (Lonza, Rockland, ME) and electrophoretically transferred to polyvinylidene fluoride membranes (Millipore) [71]. Membranes were blocked in trisbuffered saline/0.05\% Tween-20/5\% milk (1 h) at room temperature (RT). Antibodies were added to blocking buffer and membranes incubated overnight $\left(4{ }^{\circ} \mathrm{C}\right)$, washed, incubated with horseradish peroxidase-conjugated goat anti-mouse IgG secondary antibody or goat anti-rabbit IgG secondary antibody at room temperature (RT), visualized

Table 2 Antibodies

\begin{tabular}{|c|c|c|c|}
\hline Western blot-Primary antibodies & Dilution & Company: Catalog \# & $\begin{array}{l}\text { Secondary antibodies } \\
\text { Catalog \# (Dilution) }\end{array}$ \\
\hline Rabbit polyclonal antibody anti-human $\mathrm{CHI} 3 \mathrm{~L} 1$ & $1: 250$ & Abcam: ab180569 & \multirow{4}{*}{$\begin{array}{l}\text { HRP goat anti-rabbit IgG } \\
\text { Bio-Rad: } 170-6515(1: 5000)\end{array}$} \\
\hline Rabbit polyclonal antibody anti-human $\mathrm{CHI} 3 \mathrm{~L} 2$ & $1: 500$ & MyBiosource: MBS1492494 & \\
\hline Rabbit polyclonal antibody anti-lba1 & $1: 500$ & Wako: 019-19741 & \\
\hline Rabbit monoclonal anti-NPTX2 & $1: 250$ & Abcam: ab191563 & \\
\hline Mouse monoclonal anti-GFAP & $1: 500$ & Millipore: MAB3402 & \multirow{4}{*}{$\begin{array}{l}\text { HRP goat anti-mouse IgG } \\
\text { Bio-Rad: } 170-6516(1: 8000)\end{array}$} \\
\hline Mouse monoclonal anti-human CD44 & $1: 250$ & Thermofisher: MA5-13890 & \\
\hline Mouse monoclonal anti-C1q & $1: 250$ & Abcam: ab71089 & \\
\hline Mouse monoclonal anti- $\beta$-tubulin & $1: 4000$ & Millipore: MAB3408 & \\
\hline Immunostaining-Primary antibodies & $\begin{array}{l}\text { Dilution } \\
\text { IHC (IF) }\end{array}$ & Company: Catalog \# & $\begin{array}{l}\text { Secondary antibodies } \\
\text { Catalog \# (Dilution) }\end{array}$ \\
\hline Rabbit polyclonal anti-human $\mathrm{CHI} 3 \mathrm{~L} 1$ & $1: 100(1: 100)$ & Thermofisher: PA5-43746 & $\begin{array}{cc}\text { Biotinylated goat } & \text { Cy3-Donkey anti- } \\
\text { anti-rabbit IgG } & \text { rabbit lgG } \\
\text { Vector: Ba-1000 } & \text { Jackson Inc: } \\
(1: 200) & 711165152 \\
& (1: 200) \\
\end{array}$ \\
\hline Rabbit polyclonal anti-lba1 & $1: 1000$ & Wako: 019-19741 & \multirow{2}{*}{$\begin{array}{l}\text { Biotinylated goat anti-rabbit lgG } \\
\text { Vector: Ba-1000 (1:200) }\end{array}$} \\
\hline Rabbit polyclonal anti-GFAP & $1: 500$ & DAKO: Z0334 & \\
\hline Mouse monoclonal anti-human APP/A $\beta$ & $1: 2000$ & Biolegend: 803002 & $\begin{array}{c}\text { Biotinylated Goat anti-mouse lgG } \\
\text { Vector: Ba-9200 (1:200) }\end{array}$ \\
\hline Mouse monoclonal anti-human CD44 & $(1: 500)$ & $\begin{array}{c}\text { Cell Signaling: } 3670 \\
\text { Thermofisher: MA5-13890 }\end{array}$ & $\begin{array}{l}\text { Cy2-Donkey anti-mouse IgG } \\
\text { Jackson Inc: } 715225150 \text { (1:200) }\end{array}$ \\
\hline
\end{tabular}


by chemiluminescence (Kodak Image Station 440CF; Perkin-Elmer, Wellesley, MA), and quantified with Kodak 1. Protein signals were quantified and normalized to $\beta$ tubulin across groups in three independent experiments [71]. Controls consisted of either pre-absorption or deletion of the primary antibody.

\section{Immunohistochemistry}

Two 8- $\mu$ m-thick paraffin-embedded FC sections were processed for immunocytochemistry to visualize inflammatory markers, NFTs, and plaques. We chose CHI3L1 as opposed to CHI3L2 for immunohistochemical staining since the commercial CHI3L2 antibodies failed to react with the human brain tissue. Briefly, sections were pretreated with either citric acid $(\mathrm{pH}=6)$ for $20 \mathrm{~min}$ as antigen retrieval for the CHI3L1 antibody and $80 \%$ formic acid for the APP/A $\beta$ (6E10) antibody. Afterward, sections were incubated with primary antibodies against rabbit anti-CHI3L1, rabbit anti-GFAP, rabbit anti-Iba1, and mouse anti-APP/A $\beta$ or AT8 overnight at RT in a tris-buffered saline $/ 0.25 \%$ Triton X-100/1\% goat serum solution. After several washes in tris-buffered saline, tissue samples were incubated with a goat anti-rabbit/antimouse biotinylated secondary antibody, then incubated in Vectastain $A B C$ kit $(1 \mathrm{~h})$ (Vector Labs) and developed in acetate-imidazole buffer containing $0.05 \%$ 3,3' -diaminobenzidine tetrahydrochloride (DAB, Sigma, MO).

\section{Dual immunostaining}

After visualization of APP/A $\beta$ (see above), the tissue was incubated with an avidin/biotin blocking kit (Vector Labs) and second primary antibody (rabbit anti-CHI3L1) overnight at RT [72]. The next day tissue was placed in the appropriate biotinylated secondary antibody for $1 \mathrm{~h}$ at $\mathrm{RT}$, incubated in $\mathrm{ABC}$ kit solution, and developed in acetate-imidazole buffer containing 0.05\% 3,3'-DAB and $1 \%$ of nickel ammonium sulfate (Sigma). Dual staining produced a two-colored profile: APP/A $\beta$ (brown) and CHI3L1 (black). Immunohistochemical controls consisted of primary antibody omission resulting in the absence of immunoreactivity. Additional sections were stained with Gill's hematoxylin (1 min) to identify cortical layers.

\section{Immunofluorescence}

Sections were double-labeled with a mouse anti-GFAP or anti-CD44 and a rabbit anti-CHI3L1 antibody overnight. The appropriate secondary antibody was applied [Cy3-donkey anti-rabbit IgG for CHI3L1 and Cy2donkey anti-mouse IgM for GFAP] and incubated in a 0.1 thioflavin solution (10 $\mathrm{min})$ to visualize aggregated amyloid. Auto-fluorescence was blocked with Autofluorescence Eliminator Reagent (Millipore) and sections cover-slipped with aqueous mounting media (Thermo Scientific). Dual immunofluorescence was visualized, and images were acquired using the Revolve Fluorescent Microscope (Echo Laboratories, San Diego, CA, USA) with excitation filters 405, 489, and $555 \mathrm{~nm}$ for thioflavin, $\mathrm{Cy} 2$, and $\mathrm{Cy} 3$, respectively.

\section{Quantitation of CHI3L1, GFAP, and lba1 profiles}

CHI3L1 and GFAP-immunoreactive (-ir) cell counts were performed in five random fields within an area of $0.14 \mathrm{~mm}^{2}$ per field in both gray matter and white matter (WM) in two sections from the same $15 \mathrm{NCI}$, and $\mathrm{MCI}$, $14 \mathrm{mAD}$, and $5 \mathrm{sAD}$ cases. APP/A $\beta$ plaque loads and numbers and counts of AT8-positive cells within the gray matter were performed as above using tissue from the same cases. Counts of Iba1 profiles in gray matter and WM were evaluated in 6 cases/per clinical group. FC gray matter CHI3L1-ir cell counts were performed in the different cortical layers (I-II, III-IV, V-VI, and WM), while GFAP and Iba1 counts, were counted independent of cortical layer. All images and counts were acquired using a Nikon Eclipse 80i coupled with NISElements Imaging software (Nikon Americas Inc., NY). Images were corrected for contrast and luminosity using Adobe Photoshop CS4 software (Adobe Systems Inc., CA).

\section{Statistical analysis}

Data evaluated across clinical groups used Mann-Whitney, Kruskal-Wallis, Chi-square, and Wilcoxon signed-rank test followed by Conover-Inman, Holm-Šidák, Tukey, and Dunn's post hoc tests for multiple comparisons and Spearman rank for correlations (Sigma Plot 12.5, Systat Software, San Jose, CA, USA). A false discovery rate was used to adjust for multiple comparisons between correlations. Statistical significance was set at $p<0.05$ (two-tailed) and data graphically represented using GraphPad Prism 5 (GraphPad Software, San Diego, CA, USA).

\section{Results \\ Demographic, cognitive, and neuropathological characteristics}

RROS clinical groups did not differ by age, gender, education, postmortem interval, or brain weight. There were no significant differences in the number of cases carrying the ApoE $\varepsilon 4$ allele. Mini-Mental State Examination score, global cognitive score, and perceptual speed were significantly lower $(p<0.001)$ in mAD compared to MCI and NCI cases. Episodic memory z-score was significantly lower $(p<0.001)$ in mAD compared $\mathrm{t} \mathrm{NCI}$, and the visuospatial $\mathrm{z}$-score was significantly lower $(p<0.03)$ in $\mathrm{MAD}$ and $\mathrm{MCI}$ compared to that of NCI. Braak scores, CERAD, and NIA Reagan diagnosis did not differ among the clinical groups. Neuropathology revealed that $80 \%$ of $\mathrm{NCI}, 73.3 \%$ of $\mathrm{MCI}$, and $50 \%$ of $\mathrm{mAD}$ cases were Braak stages III/IV. Using NIA-Reagan criteria, 100\% of 
$\mathrm{NCI}, 86 \%$ of $\mathrm{MCI}$, and $78.5 \%$ of $\mathrm{mAD}$ were classified as low to intermediate likelihood of AD. CERAD criteria revealed that $33.3 \%$ of $\mathrm{NCI}, 20 \%$ of $\mathrm{MCI}$, and $50 \%$ of $\mathrm{mAD}$ cases were probable or definitive AD (Table 1).

The sAD cases averaged $78.33 \pm 4.47$ years of age at death (range $71-86$ years), $5.55 \pm 3.34 \mathrm{~h}$ for postmortem interval (range 2-12 h), 1122.72 $\pm 124 \mathrm{~g}$ (range 1320$980 \mathrm{~g}$ ) brain weight, $58.3 \%$ were female and average MMSE was 2.2 (range 0-9).

\section{FC amyloid plaque and NFT pathology}

FC diffuse and neuritic plaques were observed in $69.2 \%$ of NCI, $53.3 \%$ of MCI, and $100 \%$ of mAD RROS cases, while only $23 \%$ of $\mathrm{NCI}, 35.71 \%$ of $\mathrm{MCI}$, and $45.5 \%$ of mAD displayed NFTs. All severe AD cases displayed neuritic plaques and NFTs.

\section{FC CHI3L1, GFAP, and lba1 distribution and counts during $A D$ progression}

The topographic location of CHI3L1-ir cells was examined in $\mathrm{FC}$ white and gray matter across groups. In $\mathrm{NCI}$ (Fig. 1a, e, i, m), MCI (Fig. 1b, f, j, n) and mAD (Fig. 1c, $\mathrm{g}, \mathrm{k}, \mathrm{o})$ numerous CHI3L1-ir astrocytes were observed in layers I and II and WM with lesser numbers in layers III-VI. Statistical analysis revealed that the number of CHI3L1-ir cells were significantly greater in all lamina and WM in sAD (Fig. 1d, h, l, p) compared to NCI $(p<$ 0.01 ). In contrast, the numbers of Iba1-positive (Fig. $2 \mathrm{a}$, b, e, $p<0.01$ ) and GFAP-positive glial cells (Fig. 2c, d, f, $p<0.01)$ were significantly increased in MCI WM compared to that in NCI. In addition, WM Iba1-ir cells were significantly higher in mAD compared to NCI (Fig. 2e, $p<0.01)$.

Dual immunofluorescence revealed that not all GFAPir astrocytes associated with plaques were also CHI3L1positive (Fig. 3a-f), indicating that CHI3L1 co-occurs within a subset of GFAP-ir astrocytes regardless of amyloid plaques. Although a similar cortical distribution of CHI3L1-ir cells and the adhesion surface astrocyte marker CD44 was seen, not all CHI3L1-ir astrocytes coexpressed CD44 across groups (Fig. 3g-i).

Although not all CHI3L1-ir astrocytes were associated with amyloid plaques (Fig. 4a-c), CHI3L1-ir astrocytes in gray and WM were associated with blood vessels (Fig. 4d-f).

\section{FC neuroinflammatory protein levels during the progression of $A D$}

Although western blot analysis revealed no significant differences in FC CHI3L1 levels between groups, there was a trend towards an increase in AD (Fig. 5a). Conversely, CHI3L2 protein levels were significantly reduced between NCI and sAD (Fig. 5b, $p<0.01$ ). GFAP levels were unchanged across groups (Fig. 5c), whereas CD44 protein levels were significantly increased in SAD than in NCI (Fig. 5d, $p<0.01$ ). C1q and NPTX2 did not change across clinical groups (Fig. 5e, f). A subanalysis comparing protein levels between low (I-III) and high (IV-VI) Braak scores within each clinical group [73] found that NPTX2 levels were significantly higher in mAD cases with high rather than low Braak scores $(p=0.001)$.

\section{Neuroinflammatory, clinical, and neuropathological associations}

A significant correlation was found between CHI3L1 and C1q protein levels (Fig. 6a, $r=0.44, p=0.004$ ) and CHI3L1 - and Iba1-ir cell numbers in WM (Fig. 6b, $r=$ $0.61, p=0.009$ ) across NCI, MCI, and MAD. We found a significant correlation between NPTX2 and CHI3L1 protein levels across NCI and MCI (Fig. 6c, $r=0.54, p=$ $0.003)$, but not mAD. C1q and Iba1 ( $r=0.57, p=0.00005)$, CHI3L2 and CD44 (Fig. 6d, $r=-0.65, p=0.00001$ ), and GFAP and CD44 protein levels $(r=-0.49, p=0.002)$ correlated across groups. Total numbers of amyloid plaque and NFTs did not correlate with CHI3L1, CHI3L2, GFAP, and $\mathrm{C} 1 \mathrm{q}$ protein levels at any clinical stage. By contrast, we found a significant correlation between NPTX2 and total plaque load $(r=-0.46, p=0.01)$ and diffuse plaque number $(r=-0.50, p=0.007)$. In addition, a strong association was found between CHI3L2 and age $(r=-0.44, p=$ 0.0048) and CHI3L1- and Iba1-ir cell numbers were significantly correlated with episodic memory (CHI3L1, $r=$ $-0.45, p=0.003$ and Iba1, $r=-0.66, p=0.003$ ) (Fig. 6e, f) and perceptual speed (CHI3L1, $r=-0.46, p=0.002$ and Iba1, $r=-0.69, p=0.002$ ) (Fig. 6g, h) across groups.

\section{Discussion}

Although studies implicate chitinase proteins and NPTX2 in the pathogenesis of AD, their role in preclinical $\mathrm{AD}$ remains under-investigated. In the present study, we found that the numbers of FC CHI3L1positive astrocytes, mainly in gray matter layers I and II and WM, were unchanged in MCI and mild $\mathrm{AD}$, whereas in SAD, CHI3L1 cell numbers were significantly increased in all cortical layers and WM. Furthermore, FC CHI3L1 protein levels showed a positive trend to increase during disease progression, whereas CHI3L2 was significantly reduced in SAD compared to NCI. In contrast, others have shown that protein and RNA levels for these chitinases were increased in the entorhinal cortex, hippocampus, superior frontal gyrus, primary visual cortex, middle temporal gyrus, and posterior cingulate cortex in advanced AD compared to age-matched controls [74]. These observations, when taken together, suggest that chitinase levels vary between cortical regions, perhaps related to the extent and type of AD pathology. Although several studies revealed an increase in CSF CHI3L1 levels, which correlated with CSF markers for 


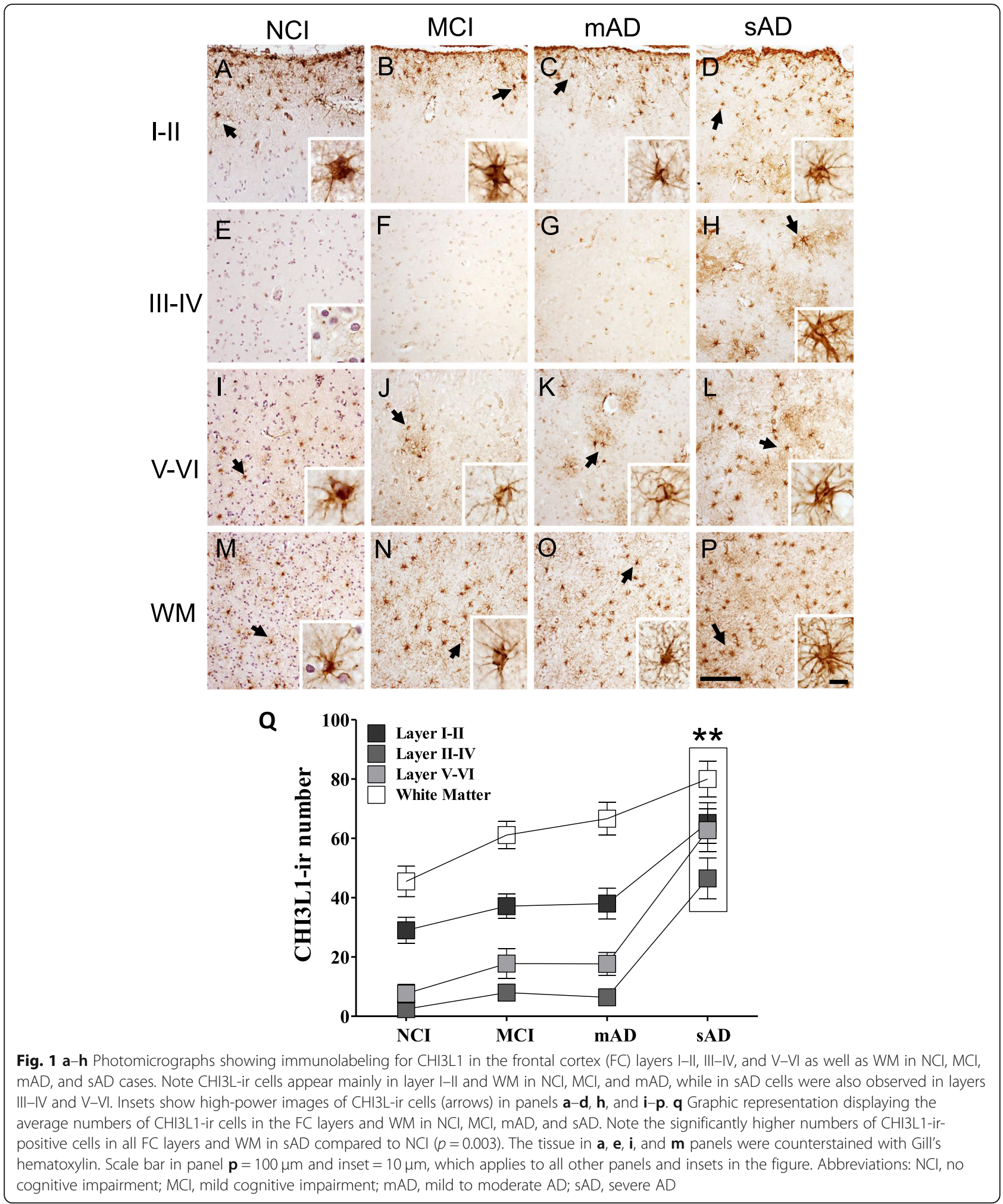

tau and amyloid in AD [75, 76], we did not find a correlation between CHI3L1 levels/counts and neuritic and diffuse plaques or NFTs. Similar to that in other reports [77], we observed CHI3L1-positive astrocytes in close apposition to amyloid plaques in $\mathrm{MCI}$ and $\mathrm{AD}$. However, many CHI3L1-ir astrocytes were independent of plaque pathology, suggesting that amyloid is not a necessary precondition for the onset of CHI3L1 expression in 


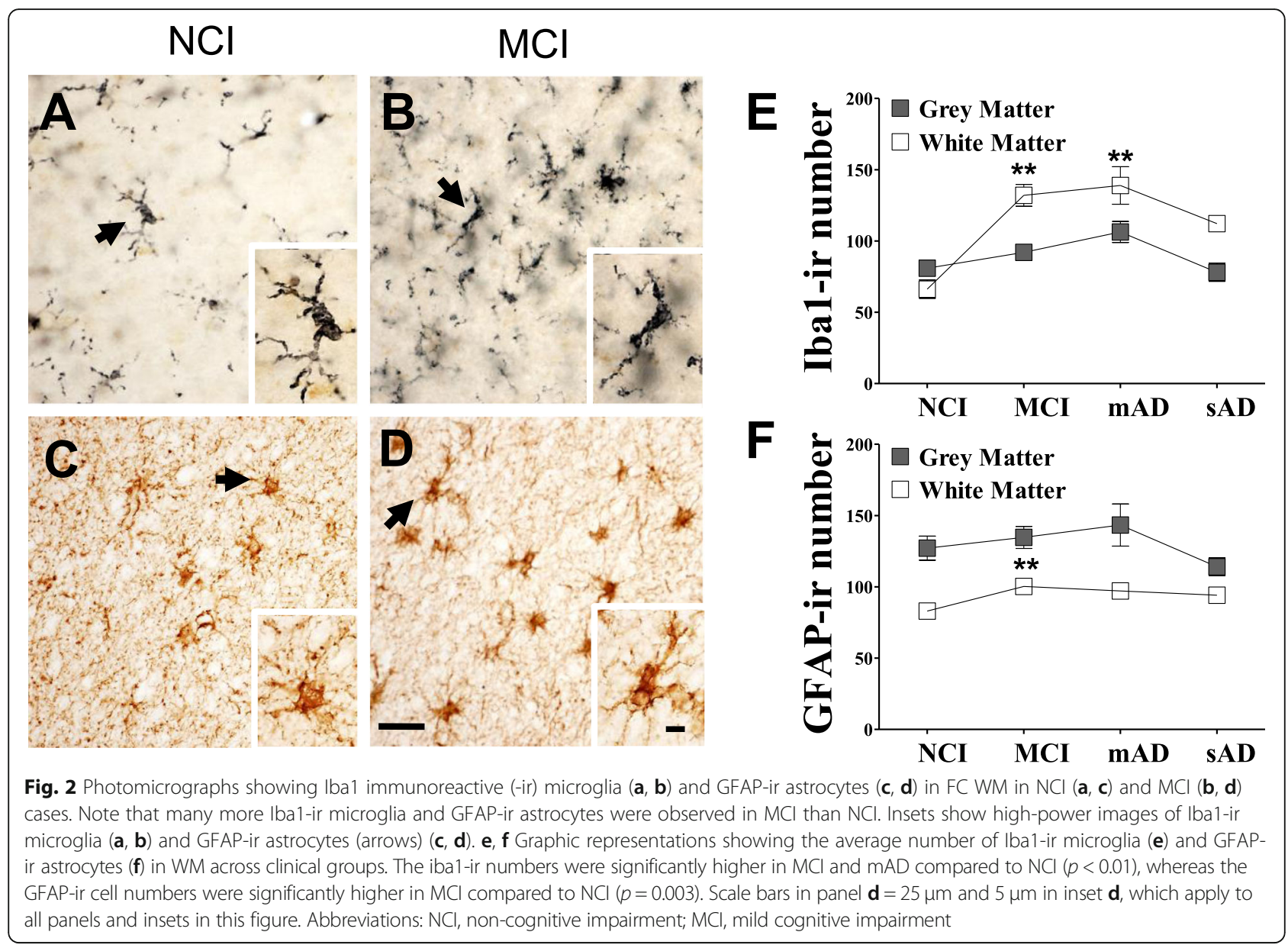

astrocytes. Moreover, we demonstrated that CHI3L1 was present in a subset of GFAP astrocytes, but neither CHI3L1 nor CHI3L2 protein levels were related to GFAP during the progression AD. In addition, GFAP levels correlated with the astrocytic surface glycoprotein adhesion molecule CD44 and the latter negatively correlated with CHI3L2. Both CHI3L2 and CD44 showed opposite effects that reached significant levels in later stages of $\mathrm{AD}$.

Interestingly, cortical CD44 was reported in a subset of astrocytes in FC layers I-II and WM in humans without cognitive impairment [78], similar to the CHI3L1 distribution observed in the present $\mathrm{NCI}$ cases. Although the distributions of CD44-positive and CHI3L1-positive astrocytes were similar, these two astrocytic markers did not colocalize. A previous study reported that CD44positive astrocytes were increased and associated with $\mathrm{A} \beta$ plaques in $\mathrm{AD}$ [79]. In the present study, although astrocytes surrounding plaques expressed GFAP, not all GFAP-positive astrocytes displayed CHI3L1 or CD44. Functionally, CD44 and chitinase-like proteins are implicated in nervous system development, homeostasis, repair, and response to injury $[80,81]$ and have the same natural ligand, hyaluronan, a component of the extracellular matrix [82]. Since we found a strong correlation between CHI3L2 and CD44 during disease progression, we speculate that the expression of these markers in astrocytes is linked to extracellular matrix disturbances. The exact mechanism that triggers the expression of these inflammatory markers and their relationship with amyloid in $\mathrm{AD}$ requires further investigation.

We found that NPTX2 correlated negatively with plaque load and was significantly higher in $\mathrm{mAD}$ cases with high Braak scores. Interestingly, toxic, soluble $A \beta$ oligomers disrupt glutamatergic synaptic function that leads to cognitive deficits [83-85]. NPTX2 also occurs in cortical pyramidal neurons, which are severely affected by tau aggregation in $\mathrm{AD}[86,87]$, suggesting a role for NPTX2 in NFT formation. These observations and the present findings of a negative correlation between NPTX2 levels and plaque load, suggests that $A \beta$ deposition modifies NPTX2 production. The significant correlation between CHI3L1 and NPTX2 in MCI and NCI suggests an interaction between astrocytes and neurons during the early stage of cognitive decline. Interestingly, changes in 

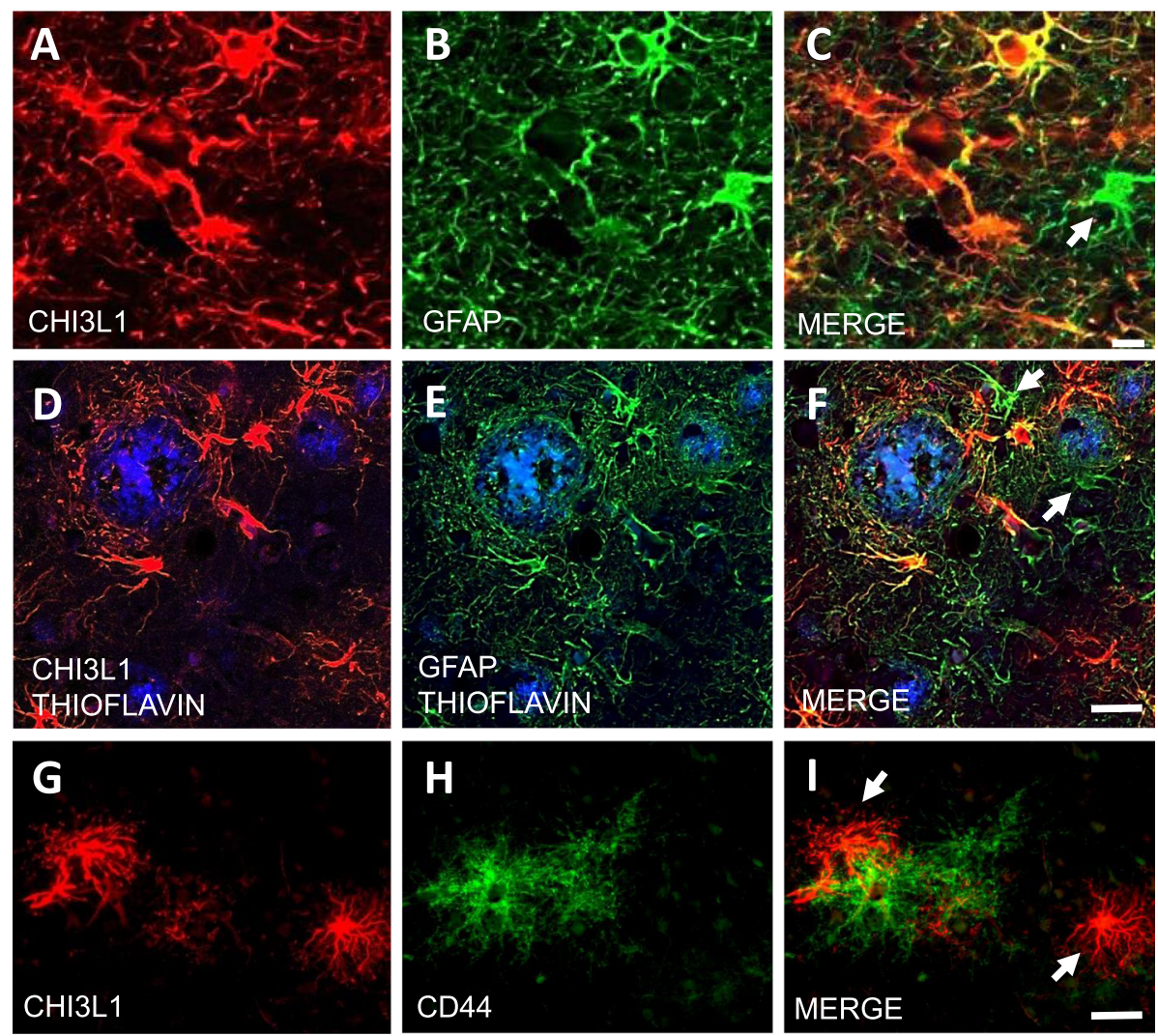

Fig. 3 a-i Double immunofluorescent images show single CHI3L1 (a, d, g) (red), GFAP (b, e) (green), and CD44 (h) (green) labeling and merged $(\mathbf{c}, \mathbf{f}, \mathbf{i})$ (orange) images in the FC in SAD. Plaques were stained with thioflavin (blue). Note that not all GFAP-positive astrocytes (white arrows) were CHI3L1-positive $(\mathbf{g}-\mathbf{i})$, and not all the CHI3L1-positive astrocytes (white arrow) were CD44-positive. Scale bar in $\mathbf{c}=10 \mu \mathrm{m}$ and applies to panels $\mathbf{a}$ and $\mathbf{b}$, and $30 \mu \mathrm{m}$ scale bars in $\mathbf{f}$ and $\mathbf{i}$ also apply to $\mathbf{d}, \mathbf{e}, \mathbf{g}$, and $\mathbf{h}$
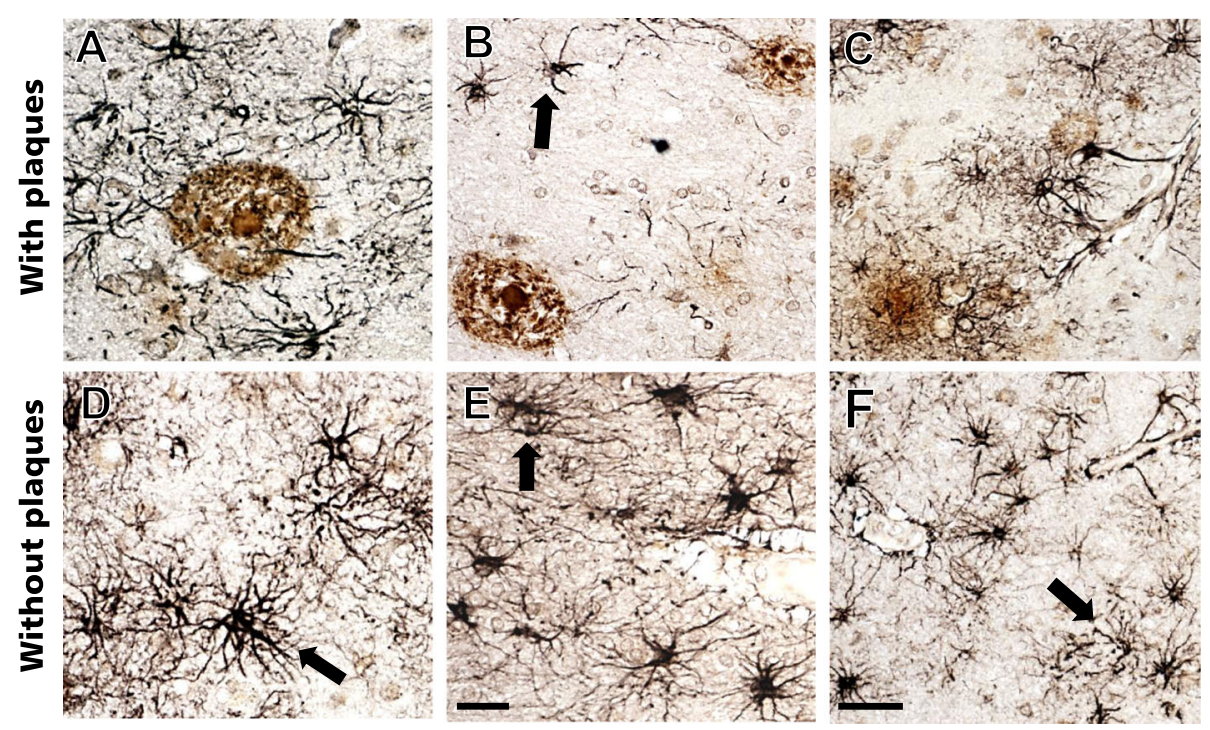

Fig. 4 a-f Photomicrographs of astrocytes dual immunolabeled for CHI3L1 (blue/black) and APP/Aß (brown) seen in plaques (a-c) as well as in areas without plaques $(\mathbf{d}-\mathbf{f})$ in SAD. Note that not all CHI3L1-positive astrocytes were associated with amyloid-positive plaques and blood vessels (arrows). Scale bar in $\mathbf{e}=50 \mu \mathrm{m}$ and applies to $\mathbf{a}, \mathbf{b}$, $\mathbf{d}$. Scale bar in $\mathbf{f}=100 \mu \mathrm{m}$ and applies to $\mathbf{c}$ 
A
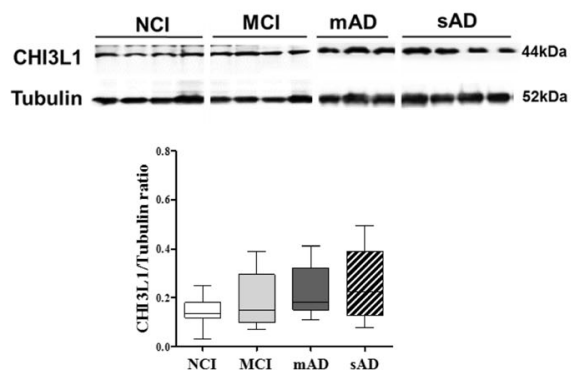

C
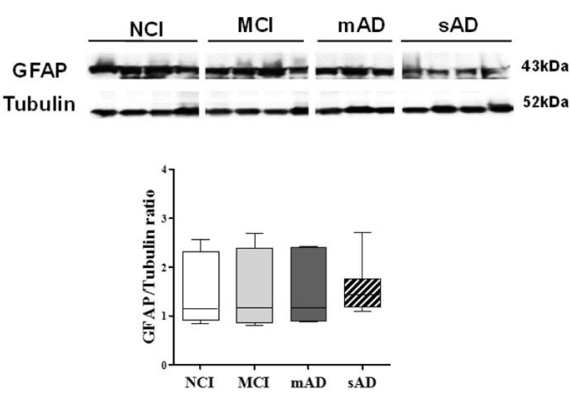

$\mathbf{E}$
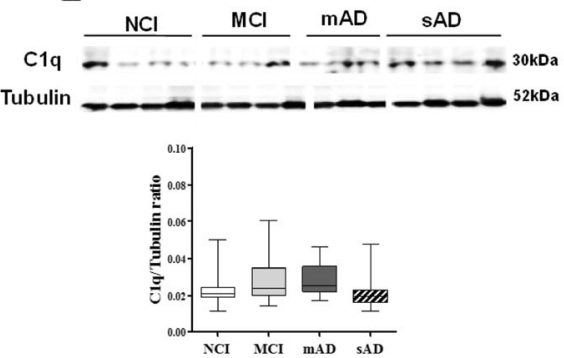

B
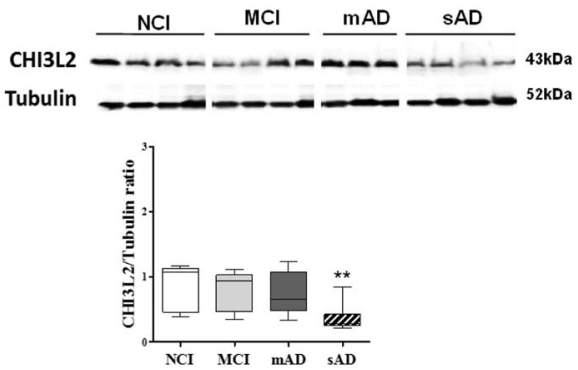

D
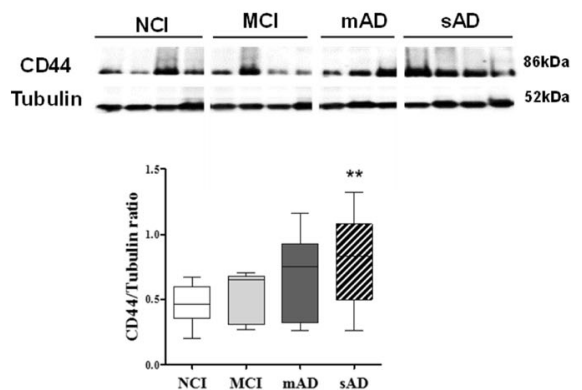

$\mathbf{F}$
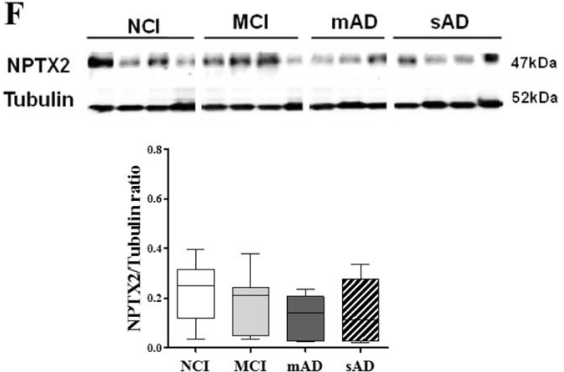

Fig. 5 Representative immunoblots and box plots showing FC levels of CHI3L1 (a), CHI3L2 (b), GFAP (c), CD44 (d), C1q (e), and NPTX2 (f) in NCI, $\mathrm{MCl}, \mathrm{mAD}$, and SAD. $\beta$-tubulin was used to normalize the immunoreactive signal obtained by densitometry. Statistical analysis revealed that CHI3L1, NPTX2, GFAP, and C1q protein levels were stable across clinical groups, whereas there was a significant decrease in CHI3L2 levels, and CD44 significantly increased in SAD compared to $\mathrm{NCl}(p=0.001)$. Abbreviations: $\mathrm{NCl}$, non-cognitive impairment; $\mathrm{MCl}$, mild cognitive impairment; $m A D$, mild to moderate $A D ; s A D$, severe $A D$

CSF CHI3L1 and NPTX2 levels are potential biomarkers for $\mathrm{AD}[88,89]$ and $\mathrm{MCI}[22]$.

Here, we report a correlation between CHI3L1 and $\mathrm{C} 1 \mathrm{q}$ protein levels in early $\mathrm{AD}$. C1q is the first component of the complement pathway [90], and microglia and astrocytes are sources of $\mathrm{C1q}$ in the $\mathrm{AD}$ brain [91, 92]. Complement-associated factors are implicated in pathogen presentation, neurodegeneration, and microglia resolution of tissue injury [93]. Here, we found a strong correlation between $\mathrm{Clq}$ and microglia Iba1 protein levels during AD progression. Microglia activation, associated with high Iba1 levels that modulate synapse loss [94] and microglia reactivity, maybe related to the induction of pro-inflammatory genes and the expression of complement-associated factors following neuronal death [95]. Perhaps, microglia activation together with $\mathrm{C} 1 \mathrm{q}$ expression activates CHI3L1 in astrocytes, which in turn plays a role in neuronal repair during $\mathrm{AD}$ progression.

We found a significant increase in Ibal and GFAP profile numbers in the WM in MCI compared to NCI. We also observed a strong negative correlation between CHI3L1-positive astrocytes and Iba1-positive microglia numbers and perceptual speed and episodic memory [96] in early AD, indicating an association between WM degeneration and early memory deficits in AD [97-100]. Since CHI3L1 is highly expressed in WM perivascular astrocytes [101] and is implicated in angiogenesis [102], it is possible that it plays a role in blood vessel conservation and remodeling during disease onset.

Furthermore, hypoperfusion induced by small-vessel disruption leads to degeneration of astrocytes and 
A

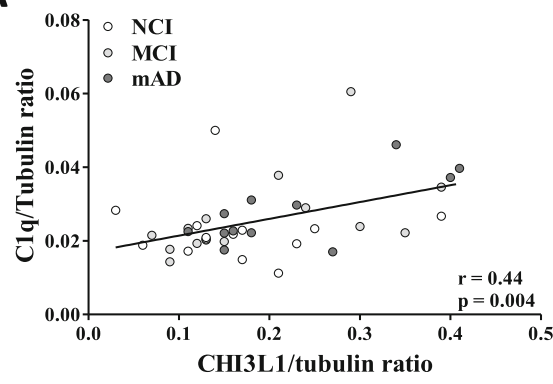

C

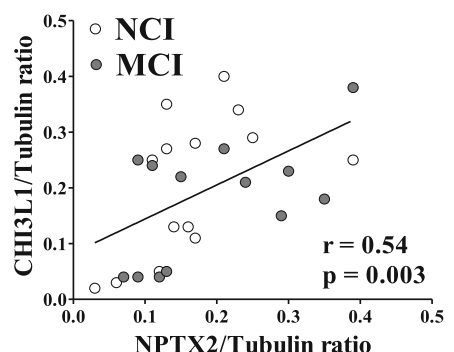

E
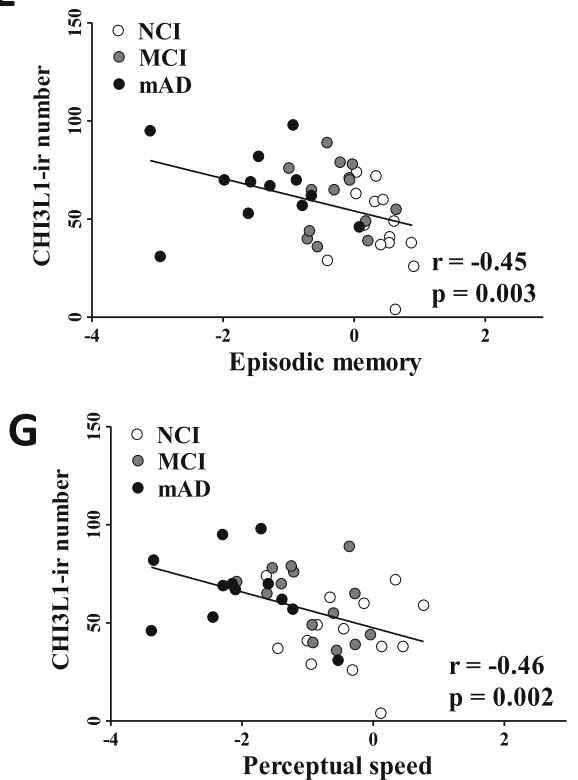

B

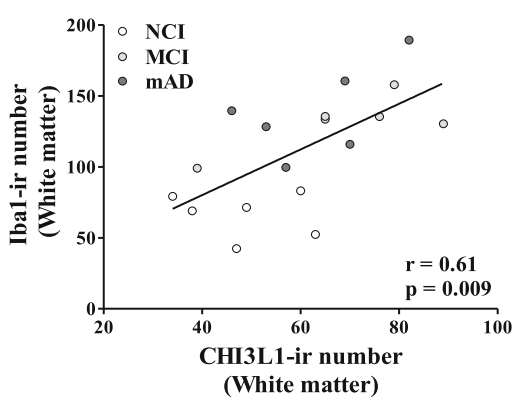

D

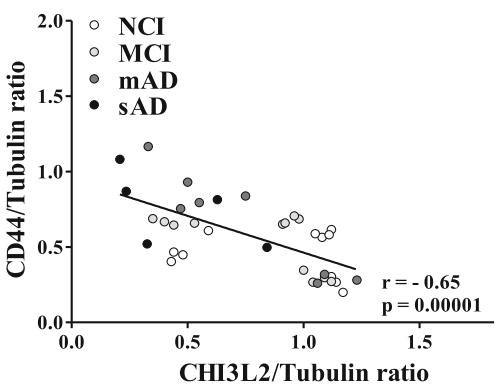

$\mathbf{F}$
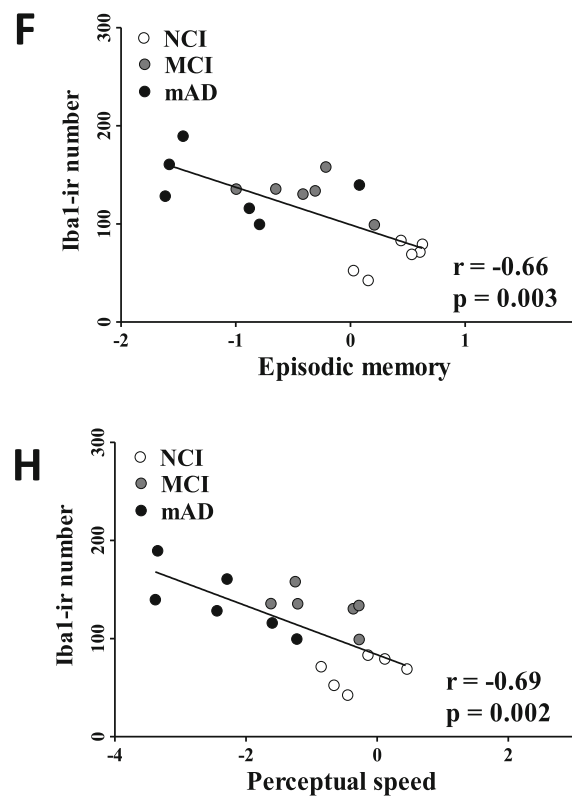

Fig. $\mathbf{6}$ a, $\mathbf{b}$ Linear regression shows a significant correlation between CHI3L1 and C1q protein levels (a), Iba1-ir and CHI3L1-ir cell numbers (b) across $\mathrm{NCl}, \mathrm{MCl}$, and mAD. $\mathbf{c}$ A significant positive correlation was observed between CHI3L1 and NPTX2 $(r=0.054, p=0.0003)$ protein levels across $\mathrm{NCl}$ and $\mathrm{MCl}$, whereas a negative correlation was seen between CD44 and CHI3L2 (d, $r=-0.65, p<0.0001)$ protein levels across the four clinical groups. In addition, positive correlations were observed between CHI3L1-ir $(\mathbf{e}, \mathbf{g})$ and Iba1-ir microglia cell numbers $(\mathbf{f}, \mathbf{h})$ with episodic memory ( $p=0.003 ; \mathbf{e}, \mathbf{f}$ ) and perceptual speed $(p=0.002 ; \mathbf{g}, \mathbf{h}$ ) across NCl, MCl, and mAD. Abbreviations: $\mathrm{NCl}$, noncognitive impairment; $\mathrm{MCl}$, mild cognitive impairment; $m A D$, mild to moderate $A D ; S A D$, severe $A D$

fibrosis of the extracellular matrix [103]. Since bloodbrain barrier (BBB) dysfunction is related to WM damage [104] and CHI3L1 is related to BBB disruption [105], we suggest that increased CHI3L1 expression in perivascular astrocytes is an attempt to remodel the blood vasculature. Perhaps a breakdown of the BBB increases CSF CHI3L1 levels, which in turn is related to cognitive dysfunction in preclinical AD [106].

The present study found a relationship between CHI3L1 and NPTX2 levels in the onset AD, further supporting 
CSF levels of these proteins as biomarkers for $\mathrm{AD}[88,89]$ and MCI [22]. NPTX2 levels marked MCI conversion to $\mathrm{AD}$ [107], improved diagnostic classification of $\mathrm{AD}$, and predicted cognitive performance in $\mathrm{MCI}$ and $\mathrm{AD}$ [108]. Together, these observations suggest that CHI3L1 and NPTX2 should be considered as novel biomarkers to improve the diagnosis and prediction of cognitive decline during the progression of $\mathrm{AD}$.

\section{Conclusion}

In summary, we demonstrated that both FC CHI3L1-ir astrocytic number and CHI3L2 and CD44 protein levels were altered in SAD. However, white matter Iba1- and GFAP-ir cell numbers were increased in MCI. Additionally, white matter CHI3L1- and Iba1-ir glial cell numbers were associated with cognitive performance during disease progression. These results suggest that WM inflammation occurs earlier than in gray matter and CHI3L1 plays a critical role in WM neuroinflammation associated with cognitive decline in AD.

\begin{abstract}
Abbreviations
AD: Alzheimer's disease; APP: Amyloid precursor protein; AB: Amyloid beta; C1q: Complement component 1q; CERAD: Consortium to Establish a Registry for Alzheimer's Disease; CHI3L1 (or YKL-40 or HC gp-39): Chitinase 3-like 1; CHI3L2 (or YKL-39): Chitinase 3-like 2; CSF: Cerebrospinal fluid; FC: Frontal cortex; GFAP: Glial fibrillary acidic protein; Iba1: Ionized calcium-binding adapter molecule 1; -ir: -Immunoreactive; mAD: Mild to moderate Alzheimer's disease; MCl: Mild cognitive impairment; $\mathrm{NCl}$ : Nocognitive impairment; NFT: Neurofibrillary tangle; NPTX2 (or Narp): Pentraxin II; RT: Room temperature; sAD: Severe Alzheimer's disease; TREM2: Triggering receptor expressed on myeloid cells 2; WM: White matter
\end{abstract}

\section{Acknowledgements}

The authors thank the nuns, priests, and brothers from across the country that participated in the Rush Religious Orders Study and the staff of the Rush Alzheimer's Disease Center. The authors thank the staff of the Neuroscience Publications at Barrow Neurological Institute for assistance with manuscript preparation.

Role of funding body in the design of the study; collection, analysis, and interpretation of the data; and writing of the manuscript Not applicable

\section{Authors' contributions}

MMR and SEP designed the study, MMR and MN performed the experiments, and MMR and MMA performed the statistical data analysis. MMR generated the figures and wrote the manuscript. SEP and EJM provided advice in the design of the study, interpretation of data, and edited the manuscript. EJM provided support for the project. All authors have read and approved the final version of the manuscript.

\section{Funding}

This work was supported by the National Institutes of Health [grant numbers P01AG14449, R01AG043375, P30AG010161, P30AG019610], Arizona Alzheimer's Disease Consortium at Barrow Neurological Institute, and Barrow Neurological Institute Barrow and Beyond and Fine Foundation.

\section{Availability of data and materials}

The conclusions in the manuscript are supported by the data presented in the text and figures.

\section{Ethics approval and consent to participate}

The Human Research Committees of Rush University Medical Center approved this study, and informed consent for research and autopsy was obtained from the Rush Religious Orders Study participants, families, or guardians.

\section{Consent for publication}

Not applicable.

\section{Competing interests}

The authors declare that they have no competing interests.

\section{Author details}

${ }^{1}$ Department of Neurobiology and Neurology, Barrow Neurological Institute, St. Joseph's Hospital and Medical Center, 350 W. Thomas Rd., Phoenix, AZ 85013, USA. Banner Alzheimer's Institute, Phoenix, AZ, USA.

Received: 21 October 2019 Accepted: 20 January 2020

Published online: 17 February 2020

\section{References}

1. Alzheimer's Association. 2016 Alzheimer's disease facts and figures. Alzheimer's Dement. 2016:12:459-509.

2. Wimo A, Guerchet M, Ali GC, Wu YT, Prina AM, Winblad B, Jonsson L, Liu Z, Prince M. The worldwide costs of dementia 2015 and comparisons with 2010. Alzheimer's Dement. 2017;13:1-7.

3. Salat DH, Kaye JA, Janowsky JS. Selective preservation and degeneration within the prefrontal cortex in aging and Alzheimer disease. Arch Neurol. 2001:58:1403-8.

4. Buckner RL, Sepulcre J, Talukdar T, Krienen FM, Liu H, Hedden T, AndrewsHanna JR, Sperling RA, Johnson KA. Cortical hubs revealed by intrinsic functional connectivity: mapping, assessment of stability, and relation to Alzheimer's disease. J Neurosci. 2009;29:1860-73.

5. Buckner RL, Snyder AZ, Shannon BJ, LaRossa G, Sachs R, Fotenos AF, Sheline YI, Klunk WE, Mathis CA, Morris JC, Mintun MA. Molecular, structural, and functional characterization of Alzheimer's disease: evidence for a relationship between default activity, amyloid, and memory. J Neurosci. 2005:25:7709-17.

6. Andrade S, Ramalho MJ, Loureiro JA, Pereira MDC. Natural compounds for Alzheimer's disease therapy: a systematic review of preclinical and clinical studies. Int J Mol Sci. 2019;20:10.

7. Naseri NN, Wang H, Guo J, Sharma M, Luo W. The complexity of tau in Alzheimer's disease. Neurosci Lett. 2019;705:183-94.

8. Akiyama H, Barger S, Barnum S, Bradt B, Bauer J, Cole GM, Cooper NR, Eikelenboom P, Emmerling M, Fiebich BL, Finch CE, Frautschy S, Griffin WS, Hampel H, Hull M, Landreth G, Lue L, Mrak R, Mackenzie IR, McGeer PL, O'Banion MK, Pachter J, Pasinetti G, Plata-Salaman C, Rogers J, Rydel R, Shen Y, Streit W, Strohmeyer R, Tooyoma I, Van Muiswinkel FL, Veerhuis R, Walker D, Webster S, Wegrzyniak B, Wenk G, Wyss-Coray T. Inflammation and Alzheimer's disease. Neurobiol Aging. 2000;21:383-421.

9. Sheng JG, Mrak RE, Griffin WS. S100 beta protein expression in Alzheimer disease: potential role in the pathogenesis of neuritic plaques. J Neurosci Res. 1994;39:398-404.

10. Kaur D, Sharma V, Deshmukh R. Activation of microglia and astrocytes: a roadway to neuroinflammation and Alzheimer's disease. Inflammopharmacology. 2019;27:663-77.

11. Boublay $N$, Federico D, Pesce A, Verny M, Blanc F, Paccalin M, Desmidt $T$, Grosmaitre P, Moreaud O, Relland S, Bravant E, Bouet R, Krolak-Salmon P. Study protocol on Alzheimer's disease and related disorders: focus on clinical and imaging predictive markers in co-existing lesions. BMC Geriatr. 2018;18:280

12. Tarkowski E, Liljeroth AM, Minthon L, Tarkowski A, Wallin A, Blennow K. Cerebral pattern of pro- and anti-inflammatory cytokines in dementias. Brain Res Bull. 2003;61:255-60.

13. Griffin MR, Daugherty J, Reed GW, Standaert SM, Hutchins SS, Hutcheson $\mathrm{RH}$, Schaffner W. Immunization coverage among infants enrolled in the Tennessee Medicaid program. Arch Pediatr Adolesc Med. 1995;149:559-64.

14. Griffin WS, Stanley LC, Ling C, White L, MacLeod V, Perrot LJ, White CL, Araoz C. Brain interleukin 1 and S-100 immunoreactivity are elevated in Down syndrome and Alzheimer disease. Proc Natl Acad Sci U S A. 1989;86: 7611-5.

15. Perez SE, Nadeem M, He B, Miguel JC, Malek-Ahmadi MH, Chen K, Mufson EJ. Neocortical and hippocampal TREM2 protein levels during the progression of Alzheimer's disease. Neurobiol Aging. 2017;54:133-43. 
16. Lu Y, Liu W, Wang X. TREM2 variants and risk of Alzheimer's disease: a metaanalysis. Neurol Sci. 2015;36:1881-8.

17. Shen Y, Yang L, Li R. What does complement do in Alzheimer's disease? Old molecules with new insights. Transl Neurodegener. 2013;2:21.

18. Itagaki S, McGeer PL, Akiyama H, Zhu S, Selkoe D. Relationship of microglia and astrocytes to amyloid deposits of Alzheimer disease. J.Neuroimmunol. 1989;24:173-82.

19. Zhang X, Fu Z, Meng L, He M, Zhang Z. The early events that initiate betaamyloid aggregation in Alzheimer's disease. Front Aging Neurosci. 2018;10:359.

20. Meraz-Rios MA, Toral-Rios D, Franco-Bocanegra D, Villeda-Hernandez J, Campos-Pena V. Inflammatory process in Alzheimer's disease. Front Integr Neurosci. 2013;7:59.

21. Lomiguen C, Vidal L, Kozlowski P, Prancan A, Stern R. Possible role of chitinlike proteins in the etiology of Alzheimer's disease. J Alzheimers Dis. 2018; 66:439-44.

22. Xiao MF, Xu D, Craig MT, Pelkey KA, Chien CC, Shi Y, Zhang J, Resnick S, Pletnikova O, Salmon D, Brewer J, Edland S, Wegiel J, Tycko B, Savonenko A, Reeves RH, Troncoso JC, McBain CJ, Galasko D, Worley PF. NPTX2 and cognitive dysfunction in Alzheimer's disease. Elife. 2017;6. https://doi.org/10. 7554/eLife.23798.

23. Liu T, Larionova I, Litviakov N, Riabov V, Zavyalova M, Tsyganov M, Buldakov M, Song B, Moganti K, Kazantseva P, Slonimskaya E, Kremmer E, Flatley A, Kluter H, Cherdyntseva N, Kzhyshkowska J. Tumor-associated macrophages in human breast cancer produce new monocyte attracting and proangiogenic factor YKL-39 indicative for increased metastasis after neoadjuvant chemotherapy. Oncoimmunology. 2018;7:e1436922.

24. Pouyafar A, Heydarabad MZ, Mahboob S, Mokhtarzadeh A, Rahbarghazi R. Angiogenic potential of YKL-40 in the dynamics of tumor niche. Biomed Pharmacother. 2018;100:478-85.

25. Hall S, Surova Y, Ohrfelt A, Swedish BioFINDER Study, Blennow K, Zetterberg $\mathrm{H}$, Hansson O. Longitudinal measurements of cerebrospinal fluid biomarkers in Parkinson's disease. Mov Disord. 2016;31:898-905.

26. Bonneh-Barkay D, Zagadailov P, Zou H, Niyonkuru C, Figley M, Starkey A, Wang G, Bissel SJ, Wiley CA, Wagner AK. YKL-40 expression in traumatic brain injury: an initial analysis. J Neurotrauma. 2010;27:1215-23.

27. Sanfilippo C, Nunnari G, Calcagno A, Malaguarnera L, Blennow K, Zetterberg $\mathrm{H}$, Di Rosa M. The chitinases expression is related to simian immunodeficiency virus encephalitis (SIVE) and in HIV encephalitis (HIVE). Virus Res. 2017;227:220-30.

28. Wiley CA, Bonneh-Barkay D, Dixon CE, Lesniak A, Wang G, Bissel SJ, Kochanek PM. Role for mammalian chitinase 3-like protein 1 in traumatic brain injury. Neuropathology. 2015;35:95-106.

29. Hakansson I, Tisell A, Cassel P, Blennow K, Zetterberg H, Lundberg P, Dahle C, Vrethem M, Ernerudh J. Neurofilament levels, disease activity and brain volume during follow-up in multiple sclerosis. J Neuroinflammation. 2018; 15:209-018.

30. Bonneh-Barkay D, Bissel SJ, Wang G, Fish KN, Nicholl GC, Darko SW, MedinaFlores R, Murphey-Corb M, Rajakumar PA, Nyaundi J, Mellors JW, Bowser R, Wiley CA. YKL-40, a marker of simian immunodeficiency virus encephalitis, modulates the biological activity of basic fibroblast growth factor. Am J Pathol. 2008;173:130-43.

31. Mollgaard M, Degn M, Sellebjerg F, Frederiksen JL, Modvig S. Cerebrospinal fluid chitinase-3-like 2 and chitotriosidase are potential prognostic biomarkers in early multiple sclerosis. Eur J Neurol. 2016;23:898-905.

32. Boesen MS, Jensen PEH, Magyari M, Born AP, Uldall PV, Blinkenberg M, Sellebjerg F. Increased cerebrospinal fluid chitinase 3-like 1 and neurofilament light chain in pediatric acquired demyelinating syndromes. Mult Scler Relat Disord. 2018;24:175-83.

33. Swanson A, Wolf T, Sitzmann A, Willette AA. Neuroinflammation in Alzheimer's disease: pleiotropic roles for cytokines and neuronal pentraxins. Behav Brain Res. 2018;347:49-56.

34. Park JE, Choi KY, Kim BC, Choi SM, Song MK, Lee JJ, Kim J, Song HC, Kim HW, Ha JM, Seo EH, Song WK, Park SG, Lee JS, Lee KH. Cerebrospinal fluid biomarkers for the diagnosis of prodromal Alzheimer's disease in amnestic mild cognitive impairment. Dement Geriatr Cogn Dis Extra. 2019;9:100-13.

35. Bjerke $M$, Engelborghs $S$. Cerebrospinal fluid biomarkers for early and differential Alzheimer's disease diagnosis. J Alzheimers Dis. 2018;62: 1199-209.

36. Zhang H, Ng KP, Therriault J, Kang MS, Pascoal TA, Rosa-Neto P, Gauthier S, Alzheimer's Disease Neuroimaging Initiative. Cerebrospinal fluid phosphorylated tau, visinin-like protein-1, and chitinase-3-like protein 1 in mild cognitive impairment and Alzheimer's disease. Transl Neurodegener. 2018;7:23.

37. Kester MI, Teunissen CE, Sutphen C, Herries EM, Ladenson JH, Xiong C, Scheltens P, van der Flier WM, Morris JC, Holtzman DM, Fagan AM. Cerebrospinal fluid VILIP-1 and YKL-40, candidate biomarkers to diagnose, predict and monitor Alzheimer's disease in a memory clinic cohort. Alzheimers Res Ther. 2015;7:59.

38. Bonneh-Barkay D, Wang G, Starkey A, Hamilton RL, Wiley CA. In vivo CHI3L1 (YKL-40) expression in astrocytes in acute and chronic neurological diseases. J Neuroinflammation. 2010;7:34.

39. Garlanda C, Bottazzi B, Salvatori G, De Santis R, Cotena A, Deban L, Maina V, Moalli F, Doni A, Veliz-Rodriguez T, Mantovani A. Pentraxins in innate immunity and inflammation. Novartis Found Symp. 2006;279:80-6.

40. Garlanda C, Bottazzi B, Bastone A, Mantovani A. Pentraxins at the crossroads between innate immunity, inflammation, matrix deposition, and female fertility. Annu Rev Immunol. 2005;23:337-66.

41. Xu D, Hopf C, Reddy R, Cho RW, Guo L, Lanahan A, Petralia RS, Wenthold RJ O'Brien RJ, Worley P. Narp and NP1 form heterocomplexes that function in developmental and activity-dependent synaptic plasticity. Neuron. 2003;39: $513-28$.

42. O'Brien RJ, Xu D, Petralia RS, Steward O, Huganir RL, Worley P. Synaptic clustering of AMPA receptors by the extracellular immediate-early gene product Narp. Neuron. 1999;23:309-23.

43. Miskimon M, Han S, Lee JJ, Ringkamp M, Wilson MA, Petralia RS, Dong X, Worley PF, Baraban JM, Reti IM. Selective expression of Narp in primary nociceptive neurons: role in microglia/macrophage activation following nerve injury. J Neuroimmunol. 2014;274:86-95.

44. Swanson A, Willette AA. Alzheimer's disease neuroimaging initiative. Neuronal pentraxin 2 predicts medial temporal atrophy and memory decline across the Alzheimer's disease spectrum. Brain Behav Immun. 2016;58:201-8.

45. Melah KE, Lu SY, Hoscheidt SM, Alexander AL, Adluru N, Destiche DJ, Carlsson CM, Zetterberg H, Blennow K, Okonkwo OC, Gleason CE, Dowling NM, Bratzke LC, Rowley HA, Sager MA, Asthana S, Johnson SC, Bendlin BB. Cerebrospinal fluid markers of Alzheimer's disease pathology and microglial activation are associated with altered white matter microstructure in asymptomatic adults at risk for Alzheimer's disease. J Alzheimers Dis. 2016; 50:873-86.

46. Calsolaro V, Edison P. Neuroinflammation in Alzheimer's disease: current evidence and future directions. Alzheimers Dement. 2016;12:719-32.

47. Geng B, Pan J, Zhao T, Ji J, Zhang C, Che Y, Yang J, Shi H, Li J, Zhou H, Mu X, Xu C, Wang C, Xu Y, Liu Z, Wen H, You Q. Chitinase 3-like 1-CD44 interaction promotes metastasis and epithelial-to-mesenchymal transition through beta-catenin/Erk/Akt signaling in gastric cancer. J Exp Clin Cancer Res. 2018;37:208-018.

48. Uberti D, Cenini G, Bonini SA, Barcikowska M, Styczynska M, Szybinska A, Memo M. Increased CD44 gene expression in lymphocytes derived from Alzheimer disease patients. Neurodegener Dis. 2010;7:143-7.

49. Perez SE, Getova DP, He B, Counts SE, Geula C, Desire L, Coutadeur S, Peillon H, Ginsberg SD, Mufson EJ. Rac1b increases with progressive tau pathology within cholinergic nucleus basalis neurons in Alzheimer's disease. Am J Pathol. 2012;180:526-40.

50. Schmitt FA, Nelson PT, Abner E, Scheff S, Jicha GA, Smith C, Cooper G, Mendiondo M, Danner DD, Van Eldik LJ, Caban-Holt A, Lovell MA, Kryscio RJ. University of Kentucky Sanders-Brown healthy brain aging volunteers: donor characteristics, procedures and neuropathology. Curr Alzheimer Res. 2012;9: 724-33.

51. Davis DG, Schmitt FA, Wekstein DR, Markesbery WR. Alzheimer neuropathologic alterations in aged cognitively normal subjects. J Neuropathol Exp Neurol. 1999;58:376-88.

52. Bennett DA, Schneider JA, Bienias JL, Evans DA, Wilson RS. Mild cognitive impairment is related to Alzheimer disease pathology and cerebral infarctions. Neurology. 2005;64:834-41.

53. Mufson EJ, Chen EY, Cochran EJ, Beckett LA, Bennett DA, Kordower JH. Entorhinal cortex beta-amyloid load in individuals with mild cognitive impairment. Exp Neurol. 1999;158:469-90.

54. McKhann G, Drachman D, Folstein M, Katzman R, Price D, Stadlan EM. Clinical diagnosis of Alzheimer's disease: report of the NINCDS-ADRDA Work Group under the auspices of Department of Health and Human Services Task Force on Alzheimer's disease. Neurology. 1984;34:939-44.

55. Rubin EH, Morris JC, Grant EA, Vendegna T. Very mild senile dementia of the Alzheimer type. I. Clinical assessment. Arch Neurol. 1989;46:379-82. 
56. Petersen RC, Smith GE, Ivnik RJ, Tangalos EG, Schaid DJ, Thibodeau SN Kokmen E, Waring SC, Kurland LT. Apolipoprotein E status as a predictor of the development of Alzheimer's disease in memory-impaired individuals. JAMA. 1995;273:1274-8.

57. Ebly EM, Hogan DB, Parhad IM. Cognitive impairment in the nondemented elderly. Results from the Canadian Study of Health and Aging. Arch Neurol. 1995;52:612-9

58. Devanand DP, Folz M, Gorlyn M, Moeller JR, Stern Y. Questionable dementia: clinical course and predictors of outcome. J Am Geriatr Soc. 1997;45:321-8.

59. Albert M, Smith LA, Scherr PA, Taylor JO, Evans DA, Funkenstein HH. Use of brief cognitive tests to identify individuals in the community with clinically diagnosed Alzheimer's disease. Int J Neurosci. 1991;57:167-78.

60. Flicker C, Ferris SH, Reisberg B. Mild cognitive impairment in the elderly: predictors of dementia. Neurology. 1991;41:1006-9.

61. Mufson EJ, He B, Nadeem M, Perez SE, Counts SE, Leurgans S, Fritz J, Lah J, Ginsberg SD, Wuu J, Scheff SW. Hippocampal proNGF signaling pathways and beta-amyloid levels in mild cognitive impairment and Alzheimer disease. JNeuropathol Exp Neurol. 2012;71:1018-29.

62. Braak H, Braak E. Neuropathological stageing of Alzheimer-related changes. Acta Neuropathol. 1991;82:239-59.

63. Newell KL, Hyman BT, Growdon JH, Hedley-Whyte ET. Application of the National Institute on Aging (NIA)-Reagan Institute criteria for the neuropathological diagnosis of Alzheimer disease. J Neuropathol Exp Neurol. 1999;58:1147-55.

64. Mirra SS. The CERAD neuropathology protocol and consensus recommendations for the postmortem diagnosis of Alzheimer's disease: a commentary. Neurobiol Aging. 1997;18:591-4.

65. Montine TJ, Phelps CH, Beach TG, Bigio EH, Cairns NJ, Dickson DW, Duyckaerts C, Frosch MP, Masliah E, Mirra SS, Nelson PT, Schneider JA, Thal DR, Trojanowski JQ, Vinters HV, Hyman BT, National Institute on Aging, Alzheimer's Association. National Institute on Aging-Alzheimer's Association guidelines for the neuropathologic assessment of Alzheimer's disease: a practical approach. Acta Neuropathol. 2012;123:1-11.

66. Mufson EJ, Binder L, Counts SE, DeKosky ST, de Toledo-Morrell L, Ginsberg SD, Ikonomovic MD, Perez SE, Scheff SW. Mild cognitive impairment: pathology and mechanisms. Acta Neuropathol. 2012;123:13-30.

67. Bennett DA, Schneider JA, Arvanitakis Z, Kelly JF, Aggarwal NT, Shah RC, Wilson RS. Neuropathology of older persons without cognitive impairment from two community-based studies. Neurology. 2006;66:1837-44.

68. Bennett DA, Schneider JA, Wilson RS, Bienias JL, Arnold SE. Neurofibrillary tangles mediate the association of amyloid load with clinical Alzheimer disease and level of cognitive function. Arch Neurol. 2004;61:378-84.

69. Mufson EJ, Malek-Ahmadi M, Snyder N, Ausdemore J, Chen K, Perez SE. Braak stage and trajectory of cognitive decline in noncognitively impaired elders. Neurobiol Aging. 2016:43:101-10.

70. Mitchell TW, Nissanov J, Han LY, Mufson EJ, Schneider JA, Cochran EJ, Bennett DA, Lee VM, Trojanowski JQ, Arnold SE. Novel method to quantify neuropil threads in brains from elders with or without cognitive impairment. J Histochem Cytochem. 2000;48:1627-38.

71. Perez SE, He B, Nadeem M, Wuu J, Scheff SW, Abrahamson EE, Ikonomovic MD, Mufson EJ. Resilience of precuneus neurotrophic signaling pathways despite amyloid pathology in prodromal Alzheimer's disease. Biol Psychiatry. 2015;77:693-703.

72. Querol-Vilaseca M, Colom-Cadena M, Pegueroles J, San Martin-Paniello C, Clarimon J, Belbin O, Fortea J, Lleo A. YKL-40 (chitinase 3-like I) is expressed in a subset of astrocytes in Alzheimer's disease and other tauopathies. J Neuroinflammation. 2017;14:118-017.

73. Mufson EJ, Malek-Ahmadi M, Perez SE, Chen K. Braak staging, plaque pathology, and APOE status in elderly persons without cognitive impairment. Neurobiol Aging. 2016;37:147-53.

74. Sanfilippo C, Malaguarnera L, Di Rosa M. Chitinase expression in Alzheimer's disease and non-demented brains regions. J Neurol Sci. 2016;369:242-9.

75. Muszynski P, Groblewska M, Kulczynska-Przybik A, Kulakowska A, Mroczko B. YKL-40 as a potential biomarker and a possible target in therapeutic strategies of Alzheimer's disease. Curr Neuropharmacol. 2017;15:906-17.

76. Muszynski P, Kulczynska-Przybik A, Borawska R, Litman-Zawadzka A, Slowik A, Klimkowicz-Mrowiec A, Pera J, Dziedzic T, Mroczko B. The relationship between markers of inflammation and degeneration in the central nervous system and the blood-brain barrier impairment in Alzheimer's disease. J Alzheimers Dis. 2017;59:903-12.

77. Llorens F, Thune K, Tahir W, Kanata E, Diaz-Lucena D, Xanthopoulos K, Kovatsi E, Pleschka C, Garcia-Esparcia P, Schmitz M, Ozbay D, Correia S,
Correia A, Milosevic I, Andreoletti O, Fernandez-Borges N, Vorberg IM, Glatzel M, Sklaviadis T, Torres JM, Krasemann S, Sanchez-Valle R, Ferrer I, Zerr I. YKL-40 in the brain and cerebrospinal fluid of neurodegenerative dementias. Mol Neurodegener. 2017;12:83-017.

78. Sosunov AA, Wu X, Tsankova NM, Guilfoyle E, McKhann GM, Goldman JE. Phenotypic heterogeneity and plasticity of isocortical and hippocampal astrocytes in the human brain. J Neurosci. 2014;34:2285-98.

79. Akiyama H, Tooyama I, Kawamata T, Ikeda K, McGeer PL. Morphological diversities of CD44 positive astrocytes in the cerebral cortex of normal subjects and patients with Alzheimer's disease. Brain Res. 1993;632:249-59.

80. Kognole AA, Payne CM. Inhibition of mammalian glycoprotein YKL-40: identification of the physiological ligand. J Biol Chem. 2017;292:2624-36.

81. Toole BP. Hyaluronan-CD44 interactions in cancer: paradoxes and possibilities. Clin Cancer Res. 2009;15:7462-8.

82. Dauth S, Grevesse T, Pantazopoulos H, Campbell PH, Maoz BM, Berretta S, Parker KK. Extracellular matrix protein expression is brain region dependent. J Comp Neurol. 2016;524:1309-36.

83. Klein WL, Krafft GA, Finch CE. Targeting small Abeta oligomers: the solution to an Alzheimer's disease conundrum? Trends Neurosci. 2001;24:219-24.

84. Hsia AY, Masliah E, McConlogue L, Yu GQ, Tatsuno G, Hu K, Kholodenko D, Malenka RC, Nicoll RA, Mucke L. Plaque-independent disruption of neural circuits in Alzheimer's disease mouse models. Proc Natl Acad Sci U S A. 1999:96:3228-33.

85. Lambert MP, Barlow AK, Chromy BA, Edwards C, Freed R, Liosatos M, Morgan TE, Rozovsky I, Trommer B, Viola KL, Wals P, Zhang C, Finch CE, Krafft GA, Klein WL. Diffusible, nonfibrillar ligands derived from Abeta1-42 are potent central nervous system neurotoxins. Proc Natl Acad Sci U S A. 1998;95:6448-53.

86. Lee SJ, Wei M, Zhang C, Maxeiner S, Pak C, Calado Botelho S, Trotter J, Sterky FH, Sudhof TC. Presynaptic neuronal pentraxin receptor organizes excitatory and inhibitory synapses. J Neurosci. 2017;37:1062-80.

87. Khatoon S, Grundke-lqbal I, Iqbal K. Levels of normal and abnormally phosphorylated tau in different cellular and regional compartments of Alzheimer disease and control brains. FEBS Lett. 1994;351:80-4.

88. Bos I, Vos S, Verhey F, Scheltens P, Teunissen C, Engelborghs S, Sleegers K, Frisoni G, Blin O, Richardson JC, Bordet R, Tsolaki M, Popp J, Peyratout G, Martinez-Lage P, Tainta M, Lleo A, Johannsen P, Freund-Levi Y, Frolich L, Vandenberghe R, Westwood S, Dobricic V, Barkhof F, Legido-Quigley C, Bertram L, Lovestone S, Streffer J, Andreasson U, Blennow K, Zetterberg H, Visser PJ. Cerebrospinal fluid biomarkers of neurodegeneration, synaptic integrity, and astroglial activation across the clinical Alzheimer's disease spectrum. Alzheimers Dement. 2019;15:644-54.

89. Zetterberg H, Skillback T, Mattsson N, Trojanowski JQ, Portelius E, Shaw LM, Weiner MW, Blennow K. Alzheimer's disease neuroimaging initiative. Association of cerebrospinal fluid neurofilament light concentration with Alzheimer disease progression. JAMA Neurol. 2016;73:60-7.

90. Reid KBM. Complement component C1q: historical perspective of a functionally versatile, and structurally unusual, serum protein. Front Immunol. 2018;9:764.

91. Goetzl EJ, Schwartz JB, Abner EL, Jicha GA, Kapogiannis D. High complement levels in astrocyte-derived exosomes of Alzheimer disease. Ann Neurol. 2018:83:544-52.

92. Luchena C, Zuazo-lbarra J, Alberdi E, Matute C, Capetillo-Zarate E. Contribution of neurons and glial cells to complement-mediated synapse removal during development, aging and in Alzheimer's disease. Mediators Inflamm. 2018;2018:2530414.

93. Holers VM. Complement and its receptors: new insights into human disease. Annu Rev Immunol. 2014;32:433-59.

94. Hong S, Beja-Glasser VF, Nfonoyim BM, Frouin A, Li S, Ramakrishnan S, Merry KM, Shi Q, Rosenthal A, Barres BA, Lemere CA, Selkoe DJ, Stevens B. Complement and microglia mediate early synapse loss in Alzheimer mouse models. Science. 2016;352:712-6.

95. Kraft AD, McPherson CA, Harry GJ. Association between microglia, inflammatory factors, and complement with loss of hippocampal mossy fiber synapses induced by Trimethyltin. Neurotox Res. 2016;30:53-66.

96. Gold CA, Budson AE. Memory loss in Alzheimer's disease: implications for development of therapeutics. Expert Rev Neurother. 2008;8:1879-91.

97. Racine AM, Adluru N, Alexander AL, Christian BT, Okonkwo OC, Oh J, Cleary CA, Birdsill A, Hillmer AT, Murali D, Barnhart TE, Gallagher CL, Carlsson CM, Rowley HA, Dowling NM, Asthana S, Sager MA, Bendlin BB, Johnson SC. Associations between white matter microstructure and amyloid burden in 
preclinical Alzheimer's disease: a multimodal imaging investigation. Neuroimage Clin. 2014;4:604-14.

98. Molinuevo JL, Ripolles P, Simo M, Llado A, Olives J, Balasa M, Antonell A, Rodriquez-Fornells A, Rami L. White matter changes in preclinical Alzheimer's disease: a magnetic resonance imaging-diffusion tensor imaging study on cognitively normal older people with positive amyloid beta protein 42 levels. Neurobiol Aging. 2014;35:2671-80.

99. Heise V, Filippini N, Ebmeier KP, Mackay CE. The APOE varepsilon4 allele modulates brain white matter integrity in healthy adults. Mol Psychiatry. 2011;16:908-16.

100. Ji F, Pasternak O, Ng KK, Chong JSX, Liu S, Zhang L, Shim HY, Loke YM, Tan BY, Venketasubramanian N, Chen CL, Zhou JH. White matter microstructural abnormalities and default network degeneration are associated with early memory deficit in Alzheimer's disease continuum. Sci Rep. 2019;9:4749-019.

101. Nishikawa KC, Millis AJ. gp38K (CHI3L1) is a novel adhesion and migration factor for vascular cells. Exp Cell Res. 2003;287:79-87.

102. Shi Y, Song Y, Liu P, Li P. YKL-40 can promote angiogenesis in sporadic cerebral cavernous malformation (CCM). J Clin Neurosci. 2019;64:220-6.

103. Rosenberg GA. Extracellular matrix inflammation in vascular cognitive impairment and dementia. Clin Sci (Lond). 2017;131:425-37.

104. Wallin A, Sjogren M, Edman A, Blennow K, Regland B. Symptoms, vascular risk factors and blood-brain barrier function in relation to $C T$ white-matter changes in dementia. Eur Neurol. 2000;44:229-35.

105. da Fonseca AC, Matias D, Garcia C, Amaral R, Geraldo LH, Freitas C, Lima FR. The impact of microglial activation on blood-brain barrier in brain diseases. Front Cell Neurosci. 2014:8:362.

106. Lleo A, Alcolea D, Martinez-Lage P, Scheltens P, Parnetti L, Poirier J, Simonsen AH, Verbeek MM, Rosa-Neto P, Slot RER, Tainta M, Izaguirre A, Reijs BLR, Farotti L, Tsolaki M, Vandenbergue R, Freund-Levi Y, Verhey FRJ, Clarimon J, Fortea J, Frolich L, Santana I, Molinuevo JL, Lehmann S, Visser PJ, Teunissen CE, Zetterberg H, Blennow K. Longitudinal cerebrospinal fluid biomarker trajectories along the Alzheimer's disease continuum in the BIOMARKAPD study. Alzheimers Dement. 2019;15:742-53.

107. Smirnov D, Salmon DP, Edland SD, Vanmechelen E, Vanderstichele HM, De Wit N, Vanbrabant J, Jacobs D, Xu D, Xiao M-F, Worley PF, Galasko DR. CSF Biomarkers of amyloid, tau and synaptic damage (Neurogranin, SNAP25) and interneuron-dependent synaptic homeostasis (NPTX2) in CSF As predictors of cognitive progression in MCl and AD. ISTAART Alzheimers Dement. 2019. AAIC Abstract ID 33762.

108. Galasko DR, Smirnov D, Salmon DP, De Wit N, Jacobs D, Vanbrabant J, Vanmechelen E, Vanderstichele HM, Xu D, Xiao M-F, Worley PF. CSF Biomarkers of Synaptic Damage (Neurogranin, SNAP25) and interneurondependent synaptic homeostasis (NPTX2) improve diagnostic classification of $\mathrm{MCl}$ and $\mathrm{AD}$ and correlate with cognition. ISTAART Alzheimers Dement. 2019. AAIC Abstract ID 33463

\section{Publisher's Note}

Springer Nature remains neutral with regard to jurisdictional claims in published maps and institutional affiliations.

Ready to submit your research? Choose BMC and benefit from:

- fast, convenient online submission

- thorough peer review by experienced researchers in your field

- rapid publication on acceptance

- support for research data, including large and complex data types

- gold Open Access which fosters wider collaboration and increased citations

- maximum visibility for your research: over $100 \mathrm{M}$ website views per year

At BMC, research is always in progress.

Learn more biomedcentral.com/submissions 